\title{
Ensenyar i aprendre en un món digital
}

\author{
Mariona Domènech $\bowtie$ \\ CESIRE Centre de Documentació i Experimentació en Ciències (CDEC) (Barcelona) \\ Institut Menéndez y Pelayo (Barcelona)
}

Els ordinadors han irromput a les aules de molts centres educatius $i$ ho han fet per quedar-s'hi. Per aquesta raó em sembla oportú parlar de la nostra experiència com a docents en aules TIC i compartir reflexions sobre les seves potencialitats i propostes d'aula. En la nostra exposició anirem, com si es tractés d'un zoom, des del món digital fins a les activitats didàctiques, a través de l'escola, l'aula i els seus protagonistes, alumnat i professorat, analitzant aquells aspectes que poden incidir en l'ensenyament aprenentatge.

Paraules clau: TIC, Tecnologies de l'Aprenentatge i el Coneixement (TAC), innovació didàctica

\section{El món digital}

És important tenir-ho en compte perquè és allà, en la societat de la informació o "món digital", en el qual neixen i "viuen" les TIC. Encara que moltes propostes innovadores, sorgeixen des de la pròpia escola inspirades en les millors fonts de la pedagogia i de la didàctica (Edith Litwin, 2008), en el cas de les "noves tecnologies" -les TIC- la innovació neix fora i llavors l'escola ha de córrer al darrera intentant de seguir el pas accelerat dels canvis tecnològics.

\section{Quines característiques d'aquesta innovació hem de tenir en compte a les nostres aules?}

En primer lloc, sens dubte, l'abundància d'informació que existeix a la xarxa i l'acceleració amb la qual es va generant. Algunes dades: cada dia es creen més de mil milions de pàgines web i es generen uns 600 nous vídeos cada minut.

Si es pot accedir a tanta informació actualitzada a la xarxa, no hauríem d'aprofitar d'alguna manera aquesta potencialitat a l'aula, prioritzant la reflexió sobre la mera informació? Un exemple: a les classes de ciències de l'ESO se solen descriure, un darrere l'altre, els grups d'animals i plantes existents, en comptes de considerar el seu significat global: el model d'ésser viu. Si ho féssim així, els aspectes fonamentals es tractarien a classe i la informació que es pot obtenir en la xarxa, podria ser- vir per aplicar els coneixements construïts a altres activitats de treball autònom, sobre aspectes més específics dels organismes i de caire informatiu.

Però aquesta enorme quantitat d'informació digital, arriba als estudiants de manera molt diferent a com l'han rebuda a través dels llibres de text, filtrada, ordenada de forma lògica, estable i com a "producte acabat" (M. Area, 2011). La informació de la xarxa està desorganitzada, fragmentada i en canvi permanent, i a més ens arriba ja sigui en llenguatge verbal o en audiovisual. Aquí és on els professors hem de jugar un rol important, d'acompanyants, ajudant als alumnes perquè no "naufraguin" a la xarxa, evitar que vagin fent "zapping" d'una pàgina a una altra sense sentit. Que la informació els serveixi per generar coneixement. "La fragmentació de la informació ens ajuda a l'accedir-hi de forma ràpida i permanent, però no al coneixement i a la profunditat dels temes". (J. M. Cerezo, 2008)

Una segona característica que hauríem de considerar i que sens dubte influirà a l'escola, és la interactivitat que ofereix la xarxa: no solament de la persona amb la màquina, sinó també entre persones. El món digital és un món global i interactiu on la informació, es crea, es comparteix i es modifica entre tothom. És el marc participatiu per excel-lència i les xarxes socials en són la seva millor evidència.

Aprofitar aquest marc participatiu podria ser un estímul perquè els estudiants aprenguessin competencialment. Sens dubte el treball online afavoreix el diàleg, podria reforçar el treball cooperatiu i facili- 
tar l'aprenentatge entre iguals. Algunes investigacions recents aporten resultats interessants en aquest sentit ${ }^{1}$.

D'acord amb molts experts (C. Monereo; 2006; J. M. Cerezo, 2008; C.; M. Area, 2011) sobre el tema de TIC i educació, podríem resumir dient que els tres aspectes fonamentals que caracteritzen aquest món digital són: el canvi del "tu" al "nosaltres", del "contingut" a la "quantitat" i del "conèixer" al "trobar".

\section{Escola digital, aules digitals}

\section{I què succeeix AVUI quan aquest "món digital" treu el cap a les nostres aules?}

Que troba a uns estudiants nascuts en aquesta societat de la informació, on se senten còmodes i àgils, i a un professorat de "cultura sòlida clàssica" que es mou entre dues cultures. Els nadius digitals i els immigrants digitals de Prensky (2006). La mentalitat digital i la mentalitat lletrada, de Monereo (2005).

Ens referim a un professorat acostumat a transmetre informació als estudiants, continguda en un llibre de text i, si de cas, en altres textos. Informació que es tracta gradualment, de manera lògica i seqüencial i que se sol treballar, de forma individual per part de l'estudiant.

I ens referim també, a un estudiant que prefereix rebre la informació de múltiples fonts multimèdia, informació fragmentada o "retalls de realitat continguda en pocs bits" (J.M. Cerezo, 2008), prevalent el format visual i auditiu al textual i que li agrada treballar simultàniament amb diverses tasques, interaccionant en xarxa amb els altres.

En resum, ens trobem amb unes aules amb tecnologia del segle XIX, un professorat del segle $X X$ i un alumnat del segle $X X I$.

Òbviament, els problemes tècnics i tecnològics de les "aules del segle XIX" són els que hem de resoldre en primer lloc. Ens referim a la velocitat de connexió a la xarxa, l'adequació de les pròpies aules, vídeoprojectors, PDI, etc. Però també a l'habilitat dels usuaris (professorat i alumnat) en l'ús d'aquestes eines.

\footnotetext{
1 "El treball cooperatiu virtual amb eines web 2.0 a l'aula de Biologia: estructura, organització i avaluació amb indicadors". Mercè Guerrero Sala. Llicències d'Estudis retribuïdes. 2009/10. Departament d'Educació. Generalitat de Catalunya. http://phobos.xtec.cat/sgfprp/resum.php?codi=2048
}

\section{I que passa amb el professorat del segle $X X$ ?}

La nostra experiència ens diu que, en molts casos, davant d'una innovació els docents solen radicalitzar-se. En referència a les TIC, uns opinen "jo no vull deixar el llibre", "sempre hem treballat d'una altra manera", "es penjaran de Facebook contínuament", "no avançarem el temari"... I uns altres, en canvi, "cal substituir la manera de fer", "cal passarse al nou", "cal fer el que els agrada"...

En definitiva, es produeix un posicionament que té molt a veure amb la valoració personal que cadascun té de les TIC, amb el grau de destresa en l'ús d'aquestes eines i també amb l'accés a recursos digitals. Els experts categoritzen així la "fase inicial" de treball amb les TIC (J. Adell, 2010). És lògic que una persona experta en el maneig d'eines digitals no vegi els mateixos problemes que un principiant, i encara més si és professor... Com dominarem l'aula si no en dominem les eines?

És cert que les TIC, per si mateixes, motiven als estudiants, és el seu hàbitat, potencien la creativitat, fomenten la comunicació i la col-laboració i, en alguns casos, els permeten "visualitzar" processos i fenòmens que no ho són accessibles a simple vista; per exemple una animació sobre un procés d'infecció bacteriana o una simulació sobre la replicació del DNA.

Però no tot són avantatges, també es presenten riscos com el naufragi informatiu (què estava buscant?), la caducitat i intoxicació informatives, (no tot el que s'escriu a la xarxa està contrastat), fins i tot l'autisme comunicatiu ("penjats" a l'ordinador). Són aquestes raons, entre moltes altres, les que suggereixen que no tot val i sobretot que no tot val per portar-ho a les aules.

D'aquí es desprèn que els professors hauríem de ser hàbils a escollir els recursos, no només pels seus aspectes tècnics (qualitat dels continguts, qualitat i originalitat de l'entorn visual) i funcionals (facilitat en la seva utilització, eficaces segons els nostres objectius i versàtils) sinó també pels pedagògics, com són la seva adequació als estudiants, la potencialitat del propi recurs, què proposa fer?, així com les capacitats que fomenten: interpretació, anàlisi, resolució de problemes, grau d'autonomia. (Marquès, 2000). Però, quantes hores passem davant de l'ordinador buscant un recurs que "funcioni bé" per a tal o tal altra classe? Hauríem de compartir propostes i experiències, comparar-les i analitzar-les en tota la seva profunditat, per triar les més idònies, d'acord a uns objectius. Compartir aquests desafiaments constants que emmarquen la nostra tasca (Edith Litwin, 2003). 
L'alumnat per la seva banda, hauria de saber utilitzar programes i dominar el llenguatge escrit i l'audiovisual, hauria de ser hàbil a buscar informació, crear-la i compartir-la. Però a més a més, i sobretot, els estudiants haurien de ser capaços de saber avaluar les fonts d'informació, tenir una actitud crítica, ètica i activa amb elles.

Com veiem, el camí cap a la integració de les TIC a les aules és lent i requereix temps, molt de temps, però essencialment formació, suport, acompanyament, i lideratge, a més, clar, de recursos digitals aplicables.

Seguint aquest procés lent d'incorporació de les TIC, és possible que arribem a una "fase intermèdia" per co-evolució, per contagi. És el moment en el qual serem capaços de compartir encerts i problemes: com seqüencieu les activitats en Moodle? coneixeu el programa $X$ de mapes conceptuals? preparem conjuntament alguna activitat amb Google Maps? És el moment que desapareixen les fronteres que cadascun de nosaltres havia establert en la fase inicial, barreres que no eren sinó una defensa del que dominem i una por al desconegut. Una certa resistència al canvi.

En el moment que siguem capaços, i ho som, de compartir, de planificar i fer alguna activitat conjuntament, estarem ja parlant de com donarem les classes, més que no pas de les eines. Ens veurem capaços no només d'incorporar les TIC a les nostres aules, sinó fins i tot d'adaptar-les a uns objectius didàctics. Alguns experts reconeixen la innata capacitat d'adaptació dels "immigrants digitals", professors en aquest cas. Fins i tot no dubten a afirmar que podem actuar de catalitzadors i impulsors de les TIC, com en moltes altres innovacions. En comptes de parlar de bretxa digital entre nadius i immigrants digitals, podríem parlar de simbiosi entre els uns i els altres. Si encara hi ha una bretxa, no és en l'ús de les TIC, sinó en el context en el qual s'utilitzen (Cerezo, 2008).

Per tant, si hem arribat fins aquí, el pas següent, el pas que ens faltaria, suposaria ja una veritable integració de les TIC a l'aula, una apropiació real de les eines digitals, com ara ho són llibres i diaris, provetes i microscopis, llapis i pintures. Eines que, com les altres, assumides determinades habilitats per part de professors i alumnes, requeriran unes actituds, una mirada competencial que permeti als alumnes transformar la informació (TIC) en coneixement (TAC, Tecnologies de l'Aprenentatge $i$ el Coneixement), perquè el que volem és que els estudiants aprenguin ciències, aprenguin matemàtiques, aprenguin a argumentar, aprenguin com s'aprèn, aprenguin en fi, a ser autònoms.

\section{Com podem fer-ho?}

Amb el que s'ha dit fins a aquí, sembla que ja hauríem de tenir les peces, els aspectes a tenir en compte per poder dissenyar les nostres activitats $i$ estratègies d'aula. Com? Doncs segurament que no hauríem de considerar aspectes molt diferents dels que utilitzem en un altre tipus de tasques que no són TIC.

Creiem que les activitats han de fer més èmfasi en les competències que en les eines TIC. Han de permetre als alumnes transformar la informació en coneixement perquè els permeti apropar-se als models científics. Han de ser activitats que no només requereixin el domini de diferents llenguatges (textual, numèric i icònic) sinó la interpretació dels seus missatges. Activitats TIC que afavoreixin la interactivitat, fent èmfasi en la planificació i deliberació, de manera que l'estudiant prengui consciència del que està fent, abans d'emprendre una acció i de prendre decisions.

Això significarà que en comptes de treballar amb les TIC passem a ensenyar i aprendre amb les TAC. Dit d'una altra manera, ensenyar i aprendre competencialment:

\begin{tabular}{|c|c|}
\hline De les TIC & ...a les TAC \\
\hline $\begin{array}{l}\text { Posen l'èmfasi en el } \\
\text { coneixement del maquinari } \\
\text { i dels programes }\end{array}$ & $\begin{array}{l}\text { Han de posar l'èmfasi en les } \\
\text { competències }\end{array}$ \\
\hline Donen informació a l'estudiant & $\begin{array}{l}\text { Han de permetre transformar la } \\
\text { informació en coneixement }\end{array}$ \\
\hline $\begin{array}{l}\text { Faciliten l'observació de } \\
\text { fenòmens i processos }\end{array}$ & $\begin{array}{l}\text { Han de facilitar la construcció de } \\
\text { models_científics }\end{array}$ \\
\hline $\begin{array}{l}\text { Faciliten comunicar la } \\
\text { informació }\end{array}$ & $\begin{array}{l}\text { Han de permetre comunicar la } \\
\text { informació i els coneixements adquirits } \\
\text { emprant aquests recursos de manera } \\
\text { creativa }\end{array}$ \\
\hline $\begin{array}{l}\text { Requereixen ordenar la } \\
\text { informació, relacionar-la, } \\
\text { sintetitzar-la... }\end{array}$ & $\begin{array}{l}\text { Han de permetre a més fer } \\
\text { inferències i deduccions de nivells de } \\
\text { complexitat diferents; comprendre la } \\
\text { informació i integrar-la en els } \\
\text { esquemes previs de coneixement i } \\
\text { aplicar-lo a diverses situacions i } \\
\text { contextos }\end{array}$ \\
\hline $\begin{array}{l}\text { Requereixen el domini de llenguat- } \\
\text { ges específics bàsics } \\
\text { (textual, numèric, icònic, } \\
\text { visual, gràfic i sonor) i de les seves } \\
\text { pautes de } \\
\text { descodificació }\end{array}$ & $\begin{array}{l}\text { Requereixen la interpretació i la } \\
\text { interacció dels diferents tipus } \\
\text { d'informació, les seves fonts, i dels } \\
\text { llenguatges i suports més freqüents }\end{array}$ \\
\hline Afavoreixen la interactivitat & $\begin{array}{l}\text { Han de permetre planificar i deliberar } \\
\text { abans d'emprendre una acció, pre- } \\
\text { nent consciència del que s'està fent }\end{array}$ \\
\hline
\end{tabular}




\section{Activitats TAC, competencials}

Intentem concretar més. El nostre zoom ara s'apropa a les activitats didàctiques. Vegem-ne una proposta.

Des dels CESIREs (Centres de Suport a la Innovació i a la Recerca Educativa) vinculats al Departament d'Ensenyament, s'ha elaborat una aplicació web anomenada ARC (Aplicació de Recursos al Curriculum), que ofereix activitats, recursos i itineraris vinculats al currículum de les àrees de matemàtiques, llengües, ciències socials, ciències naturals i tecnologia. Els materials elaborats pretenen impulsar millores metodològiques, focalitzant els seus objectius en l'adquisició d'habilitats i actituds que facin a l'alumnat més competent, sumant les potencialitats que ofereixen les TICs a aquests objectius. Són activitats aplicables directament a l'aula. L'aplicació és a:

\section{http://apliense.xtec.cat/arc/}

Des del Centre de Documentació i Experimentació en Ciències, CDEC, que és el CESIRE de ciències, el professorat que va començar a dissenyar activitats per a l'aplicació ARC, va redactar uns indicadors competencials que van servir de guia i inspiració en aquest disseny, al mateix temps que van ser útils per a la seva validació com a activitats competencials. Són els que s'il.lustren en la taula del costat.

A partir d'aquesta i altres aplicacions -com Ago$r \mathrm{a}^{2}$ - també obertes i gratuïtes, els professors que estem aplicant el projecte $1 \times 1$ a l'aula en el primer cicle d'ESO hem tingut l'oportunitat d'incorporar moltes de les seves activitats a les nostres programacions. El que hem fet és dissenyar un curs virtual en una plataforma, habitualment Moodle, en la qual s'han seqüenciat totes les activitats i tasques, així com els fòrum de debat, wiki i informacions diverses.

Al nostre Departament de Ciències, organitzem el curs i les seves activitats en seqüències didàctiques com les que segueixen: "Però, que és un ser viu?"; "Cinc eren cinc"; "On viuen?"; "Sempre ha estat així?"... L'ordre dels continguts que hem seguit és diferent al "clàssic", amb l'objectiu de poder aportar-hi una mirada més transversal.
En quin mesura l'activitat

incorpora aspectes competencials?

Està contextualitzada?

Es refereix a un context quotidià, a un context real?

\section{Permet "pensar ciència"?}

Serveix per resoldre algun problema? Té per objectiu respondre a una pregunta? Posa de manifest la funcionalitat del que s'està aprenent? Es treballa a força de preguntes adequades més que amb explicacions? Contribueix a la construcció de models científics?

\section{Promou "fer ciència"?}

Fer prediccions, dissenyar experiments, buscar evidències i proves, aplicar el dubte sistemàtic, ser imaginatiu i perseverant?

\section{Potencia l'ús del llenguatge?}

Estan previstes situacions que demanen a l'alumne parlar o escriure -0 altres tipus de representació- sobre el que està aprenent?

\section{Contribueix a transformar les TIC en TAC?}

Des de la informació a la creació de coneixement

Proposa l'aplicació del què s'ha après a un altre context diferent, demanant una implicació personal de l'alumne?

\section{Fomenta aprendre a aprendre?}

Ser capaç de reconèixer les limitacions de les pròpies idees i de ferles evolucionar, no desanimar-se davant les dificultats, i compartir el saber amb els altres. Es preveuen situacions en les quals sigui necessari raonar sobre l'experiència realitzada i ser conscient del propi aprenentatge?

Fomenta l'autonomia dels alumnes?

Es preveuen situacions en les quals calgui tenir iniciativa, negociar i prendre decisions?

\section{Potencia el treball en grup cooperatiu}

a més de l'individual, que promogui argumentar, convèncer, consensuar...?

Ajuda a relacionar coneixements diversos

dins de la mateixa matèria 0 amb altres disciplines?

Indicadors competencials. CESIRE CDEC (2008).

A partir de contextos propers, les activitats proposades intenten donar resposta a les preguntes formulades a l'inici de la unitat. Activitats, unes amb TIC i altres sense, planificades d'acord amb una seqüència didàctica perquè en moltes ocasions allò

${ }^{2}$ http://alexandria.xtec.cat/mod/data/view. php?d=2\&rid=379.

Biblioteca de recursos digitales para el aula. 
que volem explicar és massa complex com per poder-ho explicitar en una única activitat didàctica, (Digna Couso, 2010).

L'esquema de planificació d'una activitat, o d'una seqüència didàctica, es mostra a continuació $i$ pretén atendre a com desenvolupar els continguts curriculars amb una mirada competencial.

\section{Aspectes que hem considerat}

- Matèria on faré l'activitat / seqüència: nivell, nombre d'alumnes

- El tema, model, activitat a tractar és rellevant? És coherent amb el currículum?

- Quins objectius d'aprenentatge em plantejo amb l'activitat d'aprenentatge?

- Com es reflectiran aquests objectius en les activitats que he proposat? (en quines preguntes? en quin punt del protocol?...)

- En quina mesura aquests objectius són adequats (massa o massa pocs; molt o poc importants) o els més adequats per a aquestes activitats?

- Quins aspectes competencials consideraré de forma explícita?

- Com seqüenciaré les activitats? En quin moment de la seqüència situo aquesta activitat?
- La faré per explorar idees sobre un tema? Per introduir conceptes? Per aplicar-los?

- És necessari que els alumnes tinguin coneixements previs? Quins?

- El context que proposo és rellevant socialment? És proper a l'alumnat, percebut com a real?

- En cas que es planifiqui més d'una sessió, on es farà cada part? Quina és la seva temporització?

- Què farà el professor en aquesta activitat? Com? Quan? I on?

- Què faran els alumnes? Com? Quan? I on? Com treballaran els alumnes? individualment, en grup, en grup cooperatiu? Quan i com interaccionaran els alumnes?

- Quins recursos em proposo utilitzar per desenvolupar l'activitat / seqüència: Protocol o full de treball per a l'alumne?

- Quin material de laboratori, TIC, o d'ús comú necessiten per a la tasca?

- Què i com avaluaré el que han après? Quines activitats d'avaluació proposo? Els criteris d'avaluació, són coherents amb els objectius proposats?

- Com avaluaré el funcionament de l'activitat i com captaré l'opinió dels alumnes?

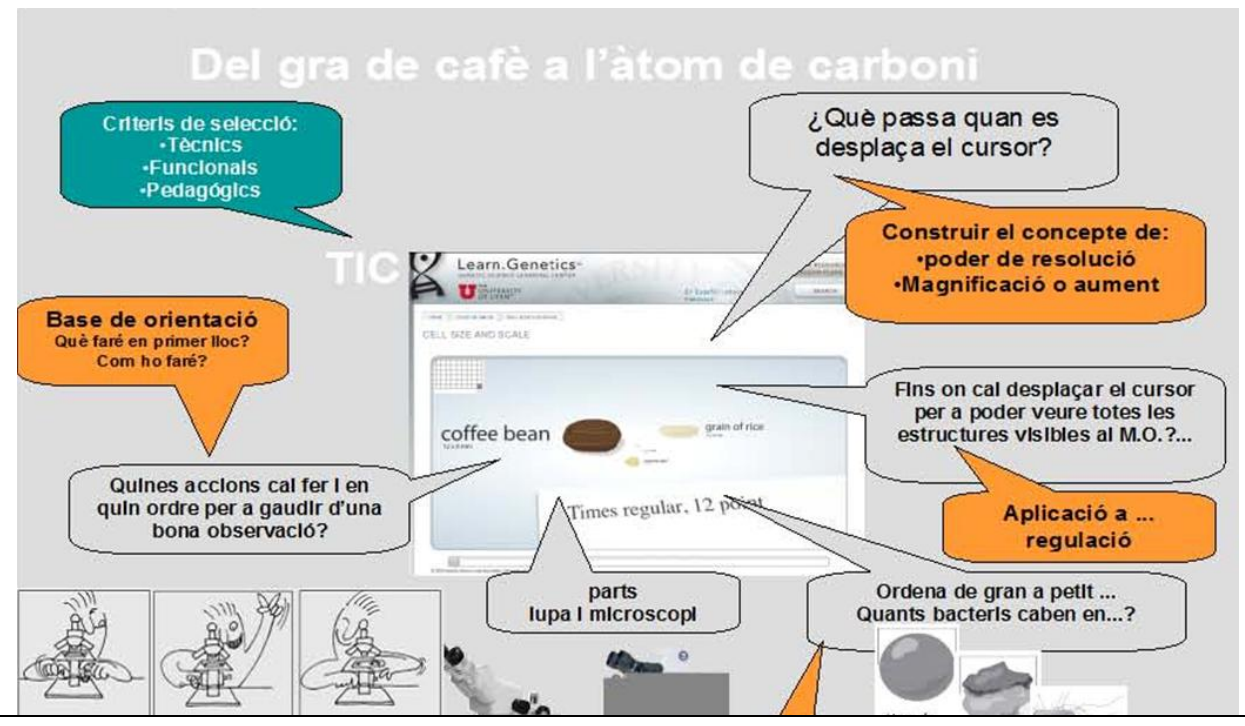

Figura 1. Presentació activitats ARC. CDEC (2008) 


\section{Parlem d'algunes activitats TIC que figuren en l'aplicació ARC}

Ja hem comentat que el que pretenem és convertir-les en activitats TAC.

En algun cas, la TIC, animació, simulació... és tan potent que l'activitat didàctica es "construeix" al seu voltant. És el cas de "Del gra de cafè a l'àtom de carboni", una animació senzilla (fig. 1) però gairebé imprescindible per tractar un aspecte essencial en biologia, el poder de resolució d'un microscopi, o d'una lupa.

Per què és important? Perquè sovint s'atribueix a aquestes eines només el seu poder de magnificar, d'augmentar, tanmateix però és la seva capacitat de "veure més coses" la que en fa un objecte essencial en els avanços científics. En aquesta activitat -0 mini-seqüència didàctica- es treballen $a$ més les unitats de mesura a través d'un joc de cartes, les parts d'un microscopi, la manera de procedir per realitzar una bona observació microscòpica, realitzant una base d'orientació com a instrument que ajudarà a l'alumne en aquesta i altres activitats.

Altres animacions, no obstant això, presenten processos o fenòmens d'una manera estàtica, "acabats", com és el cas de molts "cicles de l'aigua", en els quals tot sembla ajustat, rodant en un cicle etern aigua, processos i canvis d'estat, aliens a la realitat del planeta. En aquest cas la seqüència es planteja a partir d'una discussió sobre "Per què es diu que l'aigua és un recurs limitat?" i l'animació del cicle natural de l'aigua s'utilitza per contrastar-la amb un altre recurs digital en el qual es fan explícits els processos socials que realitzem les persones en la utilització d'aquest recurs.

En altres seqüències didàctiques, les TIC s'utilitzen només perquè els alumnes busquin informació, o bé perquè utilitzin algun programa concret, com és el cas de CmapTools, que facilita l'elaboració de mapes conceptuals. És el cas de la seqüència didàctica "Però, és un ésser viu?", que pretén apropar als estudiants al model d'ésser viu (fig. 2). Amb un "candidat" concret a ésser viu, el llevat, es planteja: els llevats tenen cèl-lules? els llevats es nodreixen? els llevats es reprodueixen? I finalment: els llevats es relacionen? Les activitats estan dissenyades a partir de contextos propers i bones preguntes que condueixen a l'alumne a expressar idees pròpies sobre el significat d'“allò que és viu". Els alumnes les responen per escrit, primer individualment, i després les contrasten en grup petit i amb tot el grup classe. Del consens passen a buscar informació a la xarxa, o bé a realitzar algun experiment que els permeti contrastar les seves idees inicials amb les oposades o bé amb els resultats de l'experiment. Finalment, i després d'estructurar els continguts en un mapa conceptual, es planteja una activitat d'aplicació que posteriorment és coavaluada pels grups-classe.

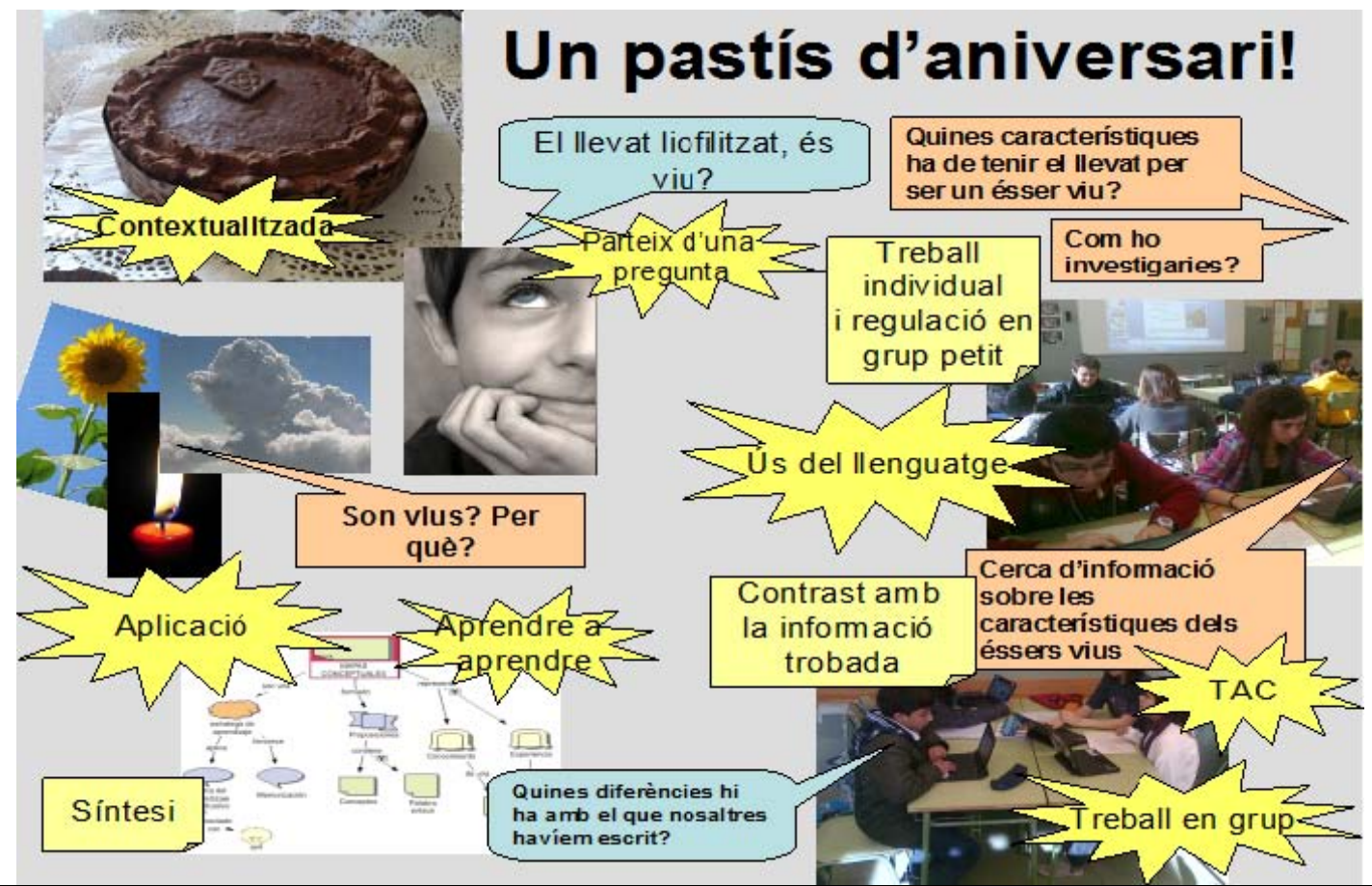

Figura 2. Presentació activitats ARC. CDEC (2008) 


\section{Conclusions}

Finalment, desitjaríem presentar alguns resultats obtinguts de la nostra experiència, sobre la percepció que tenen els alumnes de ciències de $1 r$ d'ESO de l'Institut Menéndez i Pelayo de Barcelona, en relació a la "nova" manera de treballar les ciències. Aquesta enquesta es va realitzar, a manera de "sondeig" orientatiu, per ajudar-nos a regular $\mathrm{i}$ modificar la nostra proposta.

\section{Què t'ha agradat més d'aquesta experiència? Quina ha estat per a tu "la novetat" d'aquesta matèria?}

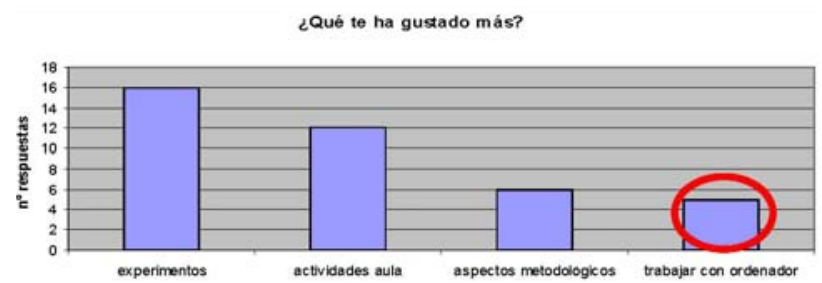

Valorem positivament que el treball per activitats, la manera de fer-ho, així com el treball experimental han estat més valorades que la pròpia eina TIC, l'ordinador, que semblava que anava a ser "l'estrella" del curs.

\section{A què penses que hem donat més importància a classe: a pensar o a memoritzar?}

Les respostes responen a: cap importància (1), poca (2), bastant (3) i molta (4).

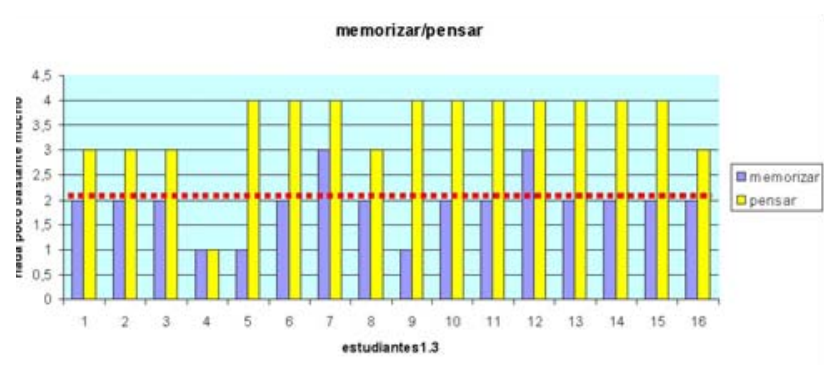

En aquest cas, valorem que els alumnes prenguin consciència i explicitin una de les finalitats del curs: "pensar ciència".
3. En quina mesura creieu que s'ha fomentat el treball cooperatiu, el treball en xarxa amb els companys i la participació a l'aula?

Les respostes responen a: gens (1), poc (2), bastant (3), molt (4):

interacció

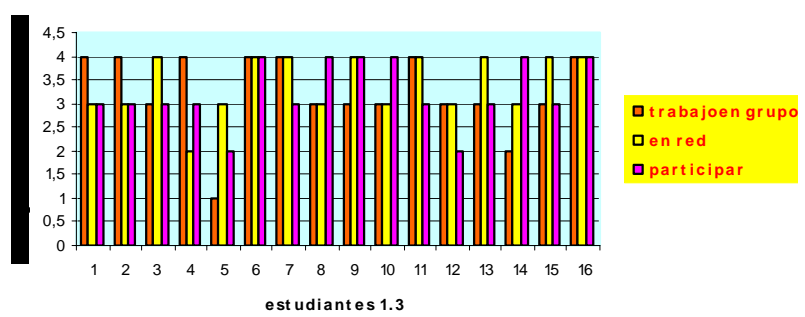

En aquesta pregunta es pretenia valorar la gestió d'aula, el nivell d'interacció i cooperació alumnealumne i també la participació a classe, i per tant la interacció professor-alumne.

\section{En quina mesura et sens ara més capaç de:} Treballar cooperativament; respondre a preguntes quotidianes; formular hipòtesis; dissenyar experiments; analitzar resultats; treballar en xarxa; treballar amb Moodle; realitzar mapes conceptuals amb CmapTools; avaluar-te; haver après i haver après més...?

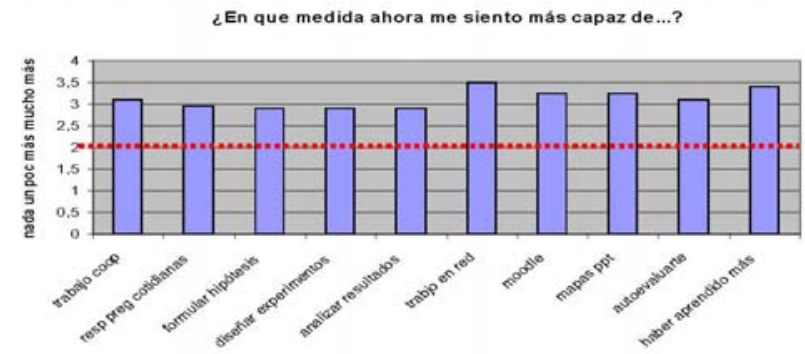

A manera de resum, en aquesta qüestió es pretenia avaluar el progrés en aspectes propis de l'aprenentatge de les ciències, en la manera de treballar, en la manera d'avaluar-se, en alguns aspectes TAC i en resum sobre el propi aprenentatge. Valorem essencialment el sentiment positiu de "haver après i haver après més".

Sens dubte, l'ofici d'ensenyar és complex i no hi ha receptes úniques que serveixin perquè els alumnes aprenguin. Però tenim eines suficients i recursos extraordinaris -alguns dels quals són TICperquè ens atrevim a fer propostes creatives que ens ajudin en la tasca com a docents. 


\section{Bibliografia}

Adell, Jordi (2010). Congreso modelos de Integración de las TIC en Educación.

http://www.ite.educacion.es/congreso/modelosti cl

Area Moreira, M i al. (2011) ¿Qué opina el profesorado sobre el Programa Escuela 2.0? Un análisis por comunidades autónomas. Proyecto de investigación Las políticas de un «ordenador por niño» en España. Instituto Nacional de Tecnologías Educativas y de Formación del Profesorado.

http://www.ite.educacion.es/es/escuela-20

Area, M. (2011): Los efectos del modelo 1:1 en el cambio educativo en las escuelas. Evidencias y desafíos para las políticas iberoamericanas. $R e$ vista Iberoamericana de Educación, 56, 49-74.

Barba,C; Capella, S. Ordinadors a les aules. La clau és la metodologia. Biblioteca de Guix, 172. Barcelona: Graó.

Barberà, E; Mauri, T; Onrubia,J;(2008).Cómo valorar la calidad de la enseñanza basada en las TIC. Pautas e instrumentos de anàlisis. Crítica y fundamentos, 19. Barcelona: Graó

Bauman, Z. (2005). Liquid life. Cambridge: Polity Press.

Cerezo, José M. (2008) Hacia un nuevo paradigma. La era de la información fragmentada. Telos, cuadernos de innovación y comunicación; №76. Madrid: Fundación Telefónica.

De Pablos, J; Area, M; Valverde, J; Correa, JM. (2010) Políticas educativas y buenas prácticas con TIC. Crítica y fundamentos, 32. Barcelona: Graó

Domènech, $M$ (2008). L'aula de ciències de secundària: de les tecnologies de la informació i la comunicació (TIC) a les tecnologies de l'aprenentatge i el coneixement (TAC), dels continguts a les competències. Ciències: Revista del Professorat de Ciències d'Infantil, Primària $i$ Secundària. n. 11, p 20. CRECIM, UAB. Barcelona.

Litwin, Edith. El oficio de enseñar. Condiciones y Contextos. (2008). Buenos Aires: Paidós.
Litwin, Edith. (2003) Los desafíos y los sinsentidos de las nuevas tecnologías en la educación. Buenos Aires: Paidós.

Marquès Graells, P (2000). Impacto de las tic en educación: funciones y limitaciones. Departament de Pedagogía Aplicada, Facultat de Educación, UAB. (última revisió: 7/08/11 )

http://peremarques. pangea.org/siyedu.htm

Monereo, C; (2005). Internet y competencias básicas. Aprender a colaborar, a comunicarse, a participar, a aprender. Barcelona: Graó.

Monereo, C; Pozo, J.I; (2007). Competencias Básicas. Cuadernos de Pedagogía. n. 370; monográfico.

Pinya, C; Piñero, A; Prat, J; Vives, N. (2011). Projectes Educatius en Xarxa. Col.lecció TAC-4. Generalitat de Catalunya. Departament d'Ensenyament.

Prensky, M. (2004)

The emerging on line life of the digital native: http://www.marcprensky.com/writing/

Ruiz, F. Món digital i escenaris de futur de l'educació. BLOG (Nov. 2011):

http://notesdopinio.blogspot.com/2011/11/mondigital-i-escenaris-de-futur-de.html

Sigalés, C; Mominó; Meneses,J M. (2009). TIC e innovación en la educación escolar española. Estado y perspectivas:

http://sociedadinformacion.fundacion.telefonica. com/DYC/TELOSonline

Vivancos, J; (2011). Ensenyament de les Ciències amb suport TAC. Taller TAC. SfeC. CDEC:

http://www.xtec.cat/cdec/

Vivancos, J; (2011). @prendre a conèixer en un món canviant. Jornada de reflexió del Consell Escolar de Catalunya. 15 de desembre 2001: www.xtec.cat/ jvivanco/aprendre_coneixer.htm

VVAA; (2011). Enseñanza de las Ciencias en la Didáctica Escolar para edades tempranas en España. Informe ENCIENDE. Madrid: COSCE.

VVAA; (2007). Experiencias innovadoras de utilización de las NTIC en actividades prácticas de ciencias. Colección Enseñanza de las Ciencias. Educación Editora. D.L. OU-123/2005 